\title{
V. Process for removing spots of grease from books and prints
}

\section{Deschamps Jun.}

To cite this article: M. Deschamps Jun. (1798) V. Process for removing spots of grease from books and prints, Philosophical Magazine Series 1, 2:5, 30-31, DOI: 10.1080/14786449808676873

To link to this article: http://dx.doi.org/10.1080/14786449808676873

曲 Published online: 18 May 2009.

Submit your article to this journal

Џll Article views: 3

Q View related articles $\square$ 
atic acid gas. This vapour, by filling the whole infide of the jar, acted upon the print; extracted the greafe as well as ink fpots; and the fragments remained pafted to the paper."

\section{Metbod of preparing the Oygenated Muriatic Acid.}

To oxygenate the muriatic acid, nothing is neceffary but to dilute it, and mix it in a very ftrong glafs veffel with manganefe, in fuch a manner that the mixture may not occupy the whole content of the glafs. Air bubbles are formed on the furface of the liquor; the empty fpace becomes filled with a greenifh vapour; and, at the end of fome hours, the acid may be further diluted with water and then ufed. It has an acid tafte, becaufe the whole is not faturated with oxygen; but it poffeffes all the virtues of the oxygenated muriatic acid. This procefs may be followed when there is not time to fet up an apparatus for diftilling, in order to procure the oxygenated acid.

V. Process for removing Spots of Greafe from Books and Prints. By M. Deschamps, Jun. Member of the Pbilofopbical Society at Lyons. From Bibliotheque Economique, Vol. $I$.

A t As TE for elegant editions, books in good prefervation, and proof impreffions of prints, can be confidered as a mania only by thofe who are unacquainted with literature. In a well printed, carefully preferved, and neat book, the fenfe feems to pafs through the organs of fight, in order to meet the underftanding; while in a bad, confufed edition, or a dirty ftained and difgufting copy, the confufion of the characters deranges, as it were, the connection of the author's thoughts; their obfcurity divefts ideas of their brilliancy; 
brilliancy; and the dirtinefs of the paper, which offends the we, makes the frubject lofe much of its charms and attraction. It is a great misfortune, therefore, to thofe who purchafe books for the fake of reading them, when the objects of their enjoyment are injured by the too clofe application of a candle or lamp. For this reafon M. Defchamps, at the requeft of a man of letters, to whom an accident of this kind had happened, devifed the following procers, which was attended with complete fuccefs :

After having gently warmed the paper ftained with greafe, wax, oil, or any fat body whatever, take out as much as poffible of it by means of bloiting paper. Then dip a fmall bruth in the effential oil of well rectified fpirit of turpentine, heated almolt to ebullition (for when cold it acts only very weakly), and draw it gently over both fides of the paper, which muft be carefully kept warm. This operation mut be repeated as many times as the quantity of the fat body imbibed by the paper, or the thicknefs of the paper, may render neceffary. When the greafy fubftance is entirely removed, recourfe may be had to the following method to reftore the paper to its former whitenefs, which is not completely reftored by the firtt procefs. Dip another brufh in highly rectified fpirit of wine, and draw it, in like manner, over the place which was ftained, and particularly round the edges, to remove the border, that would ftill prefent a ftain. By employing thefe means, with proper caution, the fpot will totally difappear: the paper will refume its original whitenefs; and if the procefs has been employed on a part written on with common ink, or printed with printers ink, it will experience no altertion. 